RESEARCH ARTICLE

\title{
Genetic Variability, Association and Path Coefficient Analyses in Segregating Populations of Black Gram (Vigna mungo (L.) Hepper)
}

\author{
Sathya $\mathbf{P}^{12}$, Manivannan $\mathbf{N}^{\star 2}$, Viswanathan $\mathbf{P L}^{2}$, Ganapathy $\mathbf{N}^{3}$, Karthikeyan $\mathbf{G}^{3}$ \\ ${ }^{1}$ National Pulses Research Centre, Tamil Nadu Agricultural University, Vamban-622 303 \\ ${ }^{2}$ Centre for Plant Breeding and Genetics, Tamil Nadu Agricultural University, Coimbatore - 641003. \\ ${ }^{3}$ Centre for Plant Protection Stuides, Tamil Nadu Agricultural University, Coimbatore - 641003.
}

\begin{abstract}
The experiment was conducted at the National Pulses Research Centre, Vamban, during Kharif 2020. $F_{2}$ generation of four crosses was utilized in this study. Around 150-200 single plants per cross were used for observation. The traits viz., plant height, number of branches per plant, number of cluster per plant, number of pods per cluster, number of pods per plant, 100 - seed weight and seed yield per plant recorded high PCV, GCV, high heritability along with high genetic advance as per cent of the mean. It indicated that these traits were less influenced by the environment and possessed high genetic variability. Also, these traits had a positive and significant correlation with seed yield in most of the crosses. The trait number pods per plant recorded positive and high direct effects on seed yield. Hence, based on correlation and path analyses, the number of pods per plant can be considered as a selection index for seed yield improvement programme in blackgram. However, population-specific selection indices are preferred as the association of traits varies with the populations.
\end{abstract}

Keywords : Blackgram; Segregating population; Variability studies; Correlation analysis; Path analysis

\section{INTRODUCTION:}

Blackgram is an important food legume that is widely cultivated in Asia as ashort-duration crop. It is suitable for all cropping seasons and is also cultivated as intercrop, mixed crop, catch crop, and bund crop. The nutritional quality of blackgram was high. It has high seed protein (25-26\%), carbohydrates (60\%), minerals, vitamins and is also rich in sulphur-containing amino acids (Bandi et al., 2018). Blackgram has a symbiotic association with Rhizobium bacteria; hence it can fix atmospheric nitrogen and improve soil fertility. As the world's population rises, the demand for grain legumes is also growing and agriculture is struggling to meet the increasing demands. High yielding genotypes need knowledge about existing genetic variation and the association among yield contributing characters. The development of a suitable plant breeding program is dependent on the presence of genetic variability. Heritability is an important parameter that determines the extent of expressivity of a trait. Heritability estimation and genetic advance as per cent of mean (GAM) are more useful in assessing the gain under selection than predicted heritability alone (Falconer, 1960). Yield is a highly complex trait because the number of component traits governs it.
So, an assessment of the interrelationship between the yield components and seed yield will be helpful in selecting a suitable and effective breeding program. Association analysis provides measures of relationship between the traits and assesses the chance for the mutual improvement of two desirable characters by common selection programme (Kumar et al., 2003). Estimation of correlation coefficient enables to eliminate the characters with little or no importance during selection. Path coefficient analysis suggested by Dewey and Lu (1959) proves helpful in partitioning the correlation coefficient into its direct and indirect effects. If the correlation is due to direct effect, it reflects a true and perfect relationship and such characters can be directly subjected to selection for improving yield. Hence, the present investigation was proposed to estimate the genetic variability and determine the character association by employing correlation coefficients and path analysis for obtaining a higher yield.

\section{MATERIAL AND METHODS}

The present research work was carried out at the National Pulses Research Centre, Vamban, during $K$ harif 2020. Four different cross combinations in $\mathrm{F}_{2}$ generation viz., VBN (Bg) 4 x CO 5, VBN (Bg) 4 x APK 
1, VBN (Bg) $4 \times$ Mash 1008, and CO 5 x TU 68 along with their parents were studied. In each $F_{2}$ cross combination, around 150 plants were maintained. Observations were recorded on plant height $(\mathrm{cm})$, number of branches per plant, number of clusters per plant, number of pods per cluster, the total number of pods, pod length $(\mathrm{cm})$, number of seeds per pod, 100-seed weight (g) and seed yield per plant (g). Observations were recorded on all single plants of cross combinations and parents. For each character, phenotypic and genotypic coefficients of variability (PCV and GCV) were computed based on the method given by Burton (1952). Heritability in a broad sense was estimated by the method suggested by Lush (1949). The expected genetic gain under selection was estimated by the method suggested by Johnson et al. (1955). As suggested by Dewey and Lu (1959), path coefficient analysis was carried out. The TNAUSTAT software (Manivannan, 2014) analyzed the variability, correlation, and path coefficients.

\section{RESULT AND DISCUSSION}

Variability analysis helps to identify the significant variation present among genotypes for a trait. Phenotypic Coefficient of Variation, Genotypic Coefficient of Variation, heritability and Genetic Advance as percent of mean of the four $F_{2}$ populations are presented in Table 1. The trait viz., number of branches per plant $P C V=45.99-91.70$; $\mathrm{GCV}=27.51-77.36)$, number of clusters per plant $(\mathrm{PCV}=44.39-56.00 ; \mathrm{GCV}=38.93-52.88)$, number of pods per plant $(\mathrm{PCV}=52.80-66.91 ; \mathrm{GCV}=44.83$ - 61.28) and seed yield per plant (PCV=53.85 65.89; GCV=39.76 - 49.27) had high PCV and GCV for all the four crosses. Similarly, Thirumalai and Murugan (2020) recorded higher PCV for plant height, number of branches per plant, number of clusters per plant, number of pods per cluster, number of pods per plant, and seed yield per plant. Sathees et al. (2019) observed higher GCV for the number of branches per plant, number of clusters per plant, number of pods per plant, and seed yield per plant. Days to first flowering recorded low PCV and GCV for all the crosses. The other traits viz., plant height, number of pods per cluster, pod length, number of seeds per pod, and hundred seed weight, recorded a higher phenotypic coefficient of variation than the genotypic coefficient of variation for most of the crosses. Similarly, Sushmitharaj et al. (2018) reported moderate PCV for number of seeds per pod. Moderate GCV for plant height and 100-seed weight was previously observed by Sushmitharaj et al. (2018). Bishnoi et al. (2017) observed the low GCV for pod length and number of seeds per pod.
Table 1.Variability parametersof yield components on yield per plant in $F_{2}$ generations of various crosses

\begin{tabular}{|c|c|c|c|c|c|}
\hline Character & Crosses & $\begin{array}{l}P C V \\
(\%)\end{array}$ & $\begin{array}{l}\text { GCV } \\
(\%)\end{array}$ & $\begin{array}{l}\text { Heritability } \\
\text { (\%) }\end{array}$ & $\begin{array}{c}\text { GAM } \\
(\%)\end{array}$ \\
\hline \multirow{4}{*}{$\begin{array}{l}\text { Days } \\
\text { to first } \\
\text { flowering }\end{array}$} & $\mathrm{C} 1$ & 8.23 & 7.68 & 86.98 & 14.53 \\
\hline & $\mathrm{C} 2$ & 7.69 & 7.24 & 88.52 & 13.82 \\
\hline & C3 & 8.22 & 7.57 & 84.70 & 14.14 \\
\hline & C4 & 7.69 & 7.09 & 84.98 & 13.27 \\
\hline \multirow{4}{*}{$\begin{array}{l}\text { Plant } \\
\text { height } \\
\text { (cm) }\end{array}$} & $\mathrm{C} 1$ & 22.86 & 22.63 & 97.98 & 46.14 \\
\hline & $\mathrm{C} 2$ & 21.65 & 16.43 & 57.58 & 25.68 \\
\hline & C3 & 21.12 & 18.16 & 73.95 & 32.17 \\
\hline & C4 & 28.90 & 22.79 & 62.19 & 37.02 \\
\hline \multirow{4}{*}{$\begin{array}{l}\text { Number of } \\
\text { branches } \\
\text { per plant }\end{array}$} & $\mathrm{C} 1$ & 55.41 & 37.31 & 45.34 & 51.75 \\
\hline & $\mathrm{C} 2$ & 52.19 & 34.88 & 44.65 & 48.01 \\
\hline & C3 & 91.70 & 77.36 & 71.17 & 134.44 \\
\hline & C4 & 45.99 & 27.51 & 35.78 & 33.90 \\
\hline \multirow{4}{*}{$\begin{array}{l}\text { Number } \\
\text { of clusters } \\
\text { per plant }\end{array}$} & $\mathrm{C} 1$ & 44.39 & 43.30 & 95.16 & 87.01 \\
\hline & $\mathrm{C} 2$ & 54.48 & 47.07 & 74.63 & 83.77 \\
\hline & C3 & 49.42 & 38.93 & 62.06 & 63.18 \\
\hline & C4 & 56.00 & 52.88 & 89.15 & 102.84 \\
\hline \multirow{4}{*}{$\begin{array}{l}\text { Number of } \\
\text { pods per } \\
\text { cluster }\end{array}$} & $\mathrm{C} 1$ & 34.35 & 23.72 & 47.67 & 33.73 \\
\hline & $\mathrm{C} 2$ & 28.43 & 18.69 & 43.20 & 25.30 \\
\hline & C3 & 28.73 & 16.72 & 33.85 & 20.04 \\
\hline & C4 & 26.09 & 17.39 & 44.44 & 23.88 \\
\hline \multirow{4}{*}{$\begin{array}{l}\text { Number of } \\
\text { pods per } \\
\text { plant }\end{array}$} & $\mathrm{C} 1$ & 52.80 & 52.63 & 99.38 & 108.09 \\
\hline & $\mathrm{C} 2$ & 64.99 & 55.77 & 73.62 & 98.57 \\
\hline & C3 & 60.13 & 44.83 & 55.59 & 68.86 \\
\hline & C4 & 66.91 & 61.28 & 83.89 & 115.63 \\
\hline \multirow{4}{*}{$\begin{array}{l}\text { Pod length } \\
(\mathrm{cm})\end{array}$} & $\mathrm{C} 1$ & 19.14 & 12.56 & 43.07 & 16.98 \\
\hline & $\mathrm{C} 2$ & 19.27 & 11.07 & 33.00 & 13.10 \\
\hline & C3 & 20.15 & 11.63 & 33.33 & 13.83 \\
\hline & C4 & 12.90 & 5.06 & 15.38 & 4.09 \\
\hline \multirow{4}{*}{$\begin{array}{l}\text { Number of } \\
\text { seeds per } \\
\text { pod }\end{array}$} & $\mathrm{C} 1$ & 13.54 & 12.93 & 91.28 & 25.46 \\
\hline & $\mathrm{C} 2$ & 15.73 & 7.02 & 19.90 & 6.45 \\
\hline & C3 & 16.60 & 10.29 & 38.43 & 13.14 \\
\hline & C4 & 12.09 & 1.55 & 1.64 & 0.41 \\
\hline \multirow{4}{*}{$\begin{array}{l}\text { 100-seed } \\
\text { weight (g) }\end{array}$} & $\mathrm{C} 1$ & 21.90 & 16.04 & 53.61 & 24.19 \\
\hline & C2 & 15.85 & 7.76 & 23.96 & 7.82 \\
\hline & C3 & 19.11 & 8.59 & 20.18 & 7.94 \\
\hline & C4 & 15.11 & 12.42 & 67.65 & 21.05 \\
\hline \multirow{4}{*}{$\begin{array}{l}\text { Seed yield } \\
\text { per plant } \\
\text { (g) }\end{array}$} & $\mathrm{C} 1$ & 53.85 & 48.76 & 81.99 & 90.96 \\
\hline & $\mathrm{C} 2$ & 64.03 & 49.27 & 59.21 & 78.10 \\
\hline & C3 & 65.89 & 43.55 & 43.70 & 59.31 \\
\hline & C4 & 65.66 & 39.76 & 36.67 & 49.60 \\
\hline
\end{tabular}

C1-VBN(Bg) 4 x CO 5; C2-VBN(Bg) 4 x APK 1; C3-VBN(Bg) 4 x Mash 1008; C4-CO 5 x TU 68

High heritability coupled with low genetic advance indicates the presence of non-additive gene action and selection for such traits may not be rewarding. High heritability and high genetic advance and low 
heritability accompanied with high genetic advance indicate the presence of additive gene effect. Selection may be effective in such cases (Nadarajan et al., 2018). Low heritability with low genetic advance suggests that the environment highly affects the trait. In such instances, selection would be ineffective. Days to first flowering recorded high heritability with moderate GAM for all four crosses. Plant height recorded high heritability with high GAM for all the crosses except VBN(Bg) 4 x APK 1.

Table 2. Simple correlation coefficient between yield and yield attributes in $F_{2}$ generations of various crosses in blackgram

\begin{tabular}{|c|c|c|c|c|c|c|c|c|c|c|}
\hline Character & Crosses & $D F F$ & PH & NBPP & NCPP & NPPC & NPPP & $P L$ & NSPP & HSW \\
\hline \multirow{4}{*}{$\begin{array}{l}\text { Plant height } \\
(\mathrm{cm})\end{array}$} & $\mathrm{C} 1$ & 0.04 & & & & & & & & \\
\hline & $\mathrm{C} 2$ & -0.05 & & & & & & & & \\
\hline & $\mathrm{C} 3$ & 0.11 & & & & & & & & \\
\hline & $\mathrm{C} 4$ & 0.02 & & & & & & & & \\
\hline \multirow{5}{*}{$\begin{array}{l}\text { Number of } \\
\text { branches per } \\
\text { plant }\end{array}$} & $\mathrm{C} 1$ & -0.08 & $0.41 * *$ & & & & & & & \\
\hline & $\mathrm{C} 2$ & 0.03 & $0.42 * *$ & & & & & & & \\
\hline & C3 & -0.03 & $0.18 *$ & & & & & & & \\
\hline & C4 & 0.08 & $0.41 * *$ & & & & & & & \\
\hline & C1 & -0.12 & $0.55 * *$ & $0.68 * *$ & & & & & & \\
\hline \multirow{4}{*}{$\begin{array}{l}\text { Number of } \\
\text { clusters per } \\
\text { plant }\end{array}$} & $\mathrm{C} 2$ & -0.07 & $0.50 * *$ & $0.74 * *$ & & & & & & \\
\hline & C3 & -0.03 & $0.30 * *$ & $0.73 * *$ & & & & & & \\
\hline & $\mathrm{C} 4$ & -0.03 & $0.49 * *$ & $0.53 * *$ & & & & & & \\
\hline & $\mathrm{C} 1$ & -0.14 & $0.31 * *$ & $0.18 * *$ & $0.25 * *$ & & & & & \\
\hline \multirow{4}{*}{$\begin{array}{l}\text { Number of } \\
\text { pods per } \\
\text { cluster }\end{array}$} & $\mathrm{C} 2$ & -0.15 & $0.18 *$ & $0.26 * *$ & $0.30 * *$ & & & & & \\
\hline & $\mathrm{C3}$ & 0.16 & $0.21 *$ & 0.20 * & $0.26 * *$ & & & & & \\
\hline & $\mathrm{C} 4$ & 0.02 & $0.26 * *$ & $0.29 * *$ & $0.34 * *$ & & & & & \\
\hline & $\mathrm{C} 1$ & -0.11 & $0.62 * *$ & $0.62 * *$ & $0.86 * *$ & $0.54 * *$ & & & & \\
\hline \multirow{4}{*}{$\begin{array}{l}\text { Number of } \\
\text { pods per } \\
\text { plant }\end{array}$} & $\mathrm{C} 2$ & -0.04 & $0.23 * *$ & $0.36 * *$ & $0.45 * *$ & 0.14 & & & & \\
\hline & C3 & 0.09 & 0.14 & $0.53 * *$ & $0.67 * *$ & $0.51 * *$ & & & & \\
\hline & C4 & -0.02 & $0.49 * *$ & $0.55 * *$ & $0.92 * *$ & $0.43 * *$ & & & & \\
\hline & $\mathrm{C} 1$ & 0.02 & 0.00 & 0.04 & -0.01 & 0.03 & 0.04 & & & \\
\hline \multirow{4}{*}{$\begin{array}{l}\text { Pod length } \\
(\mathrm{cm})\end{array}$} & $\mathrm{C} 2$ & -0.23 & -0.13 & 0.02 & 0.04 & 0.01 & $0.18 *$ & & & \\
\hline & C3 & 0.13 & -0.02 & -0.03 & -0.02 & 0.11 & 0.05 & & & \\
\hline & $\mathrm{C} 4$ & 0.08 & $0.28 * *$ & $0.33 * *$ & $0.29 * *$ & $0.16 *$ & $0.34 * *$ & & & \\
\hline & $\mathrm{C} 1$ & -0.04 & -0.02 & 0.07 & 0.07 & 0.06 & 0.09 & $0.81 * *$ & & \\
\hline \multirow{4}{*}{$\begin{array}{l}\text { Number of } \\
\text { seeds per } \\
\text { pod }\end{array}$} & $\mathrm{C} 2$ & -0.05 & -0.14 & 0.00 & -0.02 & 0.04 & $0.20 * *$ & $0.75 * *$ & & \\
\hline & $\mathrm{C3}$ & 0.03 & -0.10 & 0.08 & 0.09 & 0.12 & 0.10 & $0.47 * *$ & & \\
\hline & $\mathrm{C} 4$ & 0.14 & $0.26 * *$ & $0.31 * *$ & $0.40 * *$ & $0.26 * *$ & $0.41 * *$ & $0.72 * *$ & & \\
\hline & $\mathrm{C} 1$ & -0.02 & $0.42 * *$ & $0.38 * *$ & $0.52 * *$ & $0.30 * *$ & $0.57 * *$ & 0.05 & 0.06 & \\
\hline \multirow{4}{*}{$\begin{array}{l}100 \text {-s e e d } \\
\text { weight (g) }\end{array}$} & $\mathrm{C} 2$ & 0.02 & 0.04 & -0.05 & 0.15 & 0.00 & $0.30 * *$ & 0.04 & $0.18 * *$ & \\
\hline & C3 & 0.05 & 0.11 & $0.42 * *$ & $0.44 * *$ & $0.24 * *$ & $0.43 * *$ & 0.11 & 0.13 & \\
\hline & C4 & -0.08 & 0.13 & -0.05 & -0.15 & -0.09 & -0.12 & 0.11 & 0.06 & \\
\hline & $\mathrm{C} 1$ & -0.12 & $0.60 * *$ & $0.60 * *$ & $0.83 * *$ & $0.50 * *$ & $0.94 * *$ & 0.06 & 0.13 & $0.66 * *$ \\
\hline \multirow{3}{*}{$\begin{array}{l}\text { Seed yield } \\
\text { per plant (g) }\end{array}$} & $\mathrm{C} 2$ & -0.07 & $0.21 *$ & $0.34 * *$ & $0.41 * *$ & 0.16 & $0.94 * *$ & $0.19 *$ & 0.21 & $0.29 * *$ \\
\hline & $\mathrm{C3}$ & 0.12 & $0.17 *$ & $0.62 * *$ & $0.62 * *$ & $0.31 * *$ & $0.70 * *$ & -0.01 & 0.05 & $0.67 * *$ \\
\hline & C4 & -0.03 & $0.49 * *$ & $0.53 * *$ & $0.84 * *$ & $0.49 * *$ & $0.92 * *$ & $0.35 * *$ & $0.45 * *$ & 0.00 \\
\hline
\end{tabular}

C1-VBN(Bg) 4 x CO 5; C2-VBN(Bg) 4 x APK 1; C3-VBN(Bg) 4 x Mash 1008; C4-CO 5 x TU 68

*,* Significant at $5 \%$ and $1 \%$ level of probability, respectively.

Similarly, Sushmitharaj et al. (2018) recorded high heritability and high GAM for the trait plant height. High heritability with high GAM was observed for the trait number of branches per plant for the cross $\operatorname{VBN}(\mathrm{Bg}) 4 \times$ Mash 1008 . The remaining crosses recorded moderate heritability with high GAM. Thirumalai and Murugan (2020) recorded high heritability and high GAM for number of branches 
per plant. The number of clusters per plant, number of pods per plant recorded high heritability and high GAM for all the cross except VBN(Bg) 4 x Mash 1008. Sushmitharaj et al. (2018) also observed the high heritability and GAM for number of clusters per plant and number of pods per cluster. Pod length recorded moderate heritability and moderate GAM for most of the crosses. The traits number of seeds per pod and 100-seed weight recorded various levels of heritability and GAM. Seed yield per plant recorded moderate heritability and high GAM. Similar results were observed by Anuradha et al. (2020)

Table 3. Direct and indirect effect of yield components on yield per plant in $F_{2}$ generations of various crosses

\begin{tabular}{|c|c|c|c|c|c|c|c|c|c|c|c|}
\hline Character & Crosses & DFF & $P H$ & NBPP & NCPP & NPPC & NPPP & $P L$ & NSPP & HSW & $\begin{array}{l}\text { Simple correlation } \\
\text { coefficient with seed } \\
\text { yield per plant (g) }\end{array}$ \\
\hline \multirow{4}{*}{$\begin{array}{l}\text { Days to first } \\
\text { flowering }\end{array}$} & $\mathrm{C} 1$ & -0.03 & 0.00 & 0.00 & 0.00 & 0.00 & -0.08 & 0.00 & 0.00 & 0.00 & -0.12 \\
\hline & $\mathrm{C} 2$ & -0.04 & 0.00 & 0.00 & 0.00 & 0.00 & -0.03 & 0.00 & 0.00 & 0.00 & -0.07 \\
\hline & $\mathrm{C} 3$ & 0.08 & 0.00 & -0.00 & 0.00 & -0.01 & 0.04 & -0.00 & -0.00 & 0.01 & 0.11 \\
\hline & C4 & -0.02 & 0.00 & 0.00 & 0.00 & 0.00 & -0.01 & 0.00 & 0.01 & -0.01 & -0.03 \\
\hline \multirow{4}{*}{$\begin{array}{l}\text { Plant } \\
\text { height }(\mathrm{cm})\end{array}$} & $\mathrm{C} 1$ & 0.00 & 0.02 & 0.01 & 0.02 & 0.00 & 0.47 & 0.00 & 0.00 & 0.08 & $0.60 * *$ \\
\hline & $\mathrm{C} 2$ & 0.00 & 0.00 & 0.01 & -0.02 & 0.01 & 0.21 & 0.00 & 0.00 & 0.00 & $0.21 *$ \\
\hline & $\mathrm{C} 3$ & 0.01 & 0.04 & 0.04 & -0.01 & -0.01 & 0.06 & 0.00 & 0.00 & 0.04 & $0.17 *$ \\
\hline & C4 & 0.00 & 0.01 & 0.01 & 0.03 & 0.03 & 0.38 & -0.01 & 0.02 & 0.01 & $0.49 * *$ \\
\hline \multirow{4}{*}{$\begin{array}{l}\text { Number of } \\
\text { branches per } \\
\text { plant }\end{array}$} & $\mathrm{C} 1$ & 0.00 & 0.01 & 0.02 & 0.03 & 0.00 & 0.48 & 0.00 & 0.01 & 0.07 & $0.60 * *$ \\
\hline & $\mathrm{C} 2$ & 0.00 & 0.00 & 0.04 & -0.03 & 0.01 & 0.33 & 0.00 & 0.00 & 0.00 & $0.34 * *$ \\
\hline & $\mathrm{C} 3$ & -0.00 & 0.01 & 0.23 & -0.02 & -0.01 & 0.24 & 0.00 & 0.00 & 0.17 & $0.62 * *$ \\
\hline & $\mathrm{C} 4$ & 0.00 & 0.00 & 0.02 & 0.04 & 0.03 & 0.43 & -0.01 & 0.02 & -0.01 & $0.53 * *$ \\
\hline \multirow{4}{*}{$\begin{array}{l}\text { Number of } \\
\text { clusters per } \\
\text { plant }\end{array}$} & $\mathrm{C} 1$ & 0.00 & 0.01 & 0.01 & 0.04 & 0.00 & 0.66 & 0.00 & 0.01 & 0.09 & $0.83 * *$ \\
\hline & $\mathrm{C} 2$ & 0.00 & 0.00 & 0.03 & -0.05 & 0.01 & 0.42 & 0.00 & 0.00 & 0.00 & $0.41^{* *}$ \\
\hline & $\mathrm{C} 3$ & -0.00 & 0.01 & 0.17 & -0.03 & -0.02 & 0.31 & 0.00 & 0.00 & 0.18 & $0.62 * *$ \\
\hline & C4 & 0.00 & 0.00 & 0.01 & 0.07 & 0.04 & 0.71 & -0.01 & 0.03 & -0.02 & $0.84 * *$ \\
\hline \multirow{4}{*}{$\begin{array}{l}\text { Number of } \\
\text { pods per } \\
\text { cluster }\end{array}$} & $\mathrm{C} 1$ & 0.00 & 0.01 & 0.00 & 0.01 & 0.01 & 0.42 & 0.00 & 0.01 & 0.05 & $0.50 * *$ \\
\hline & $\mathrm{C} 2$ & 0.01 & 0.00 & 0.01 & -0.01 & 0.03 & 0.13 & 0.00 & 0.00 & 0.00 & 0.16 \\
\hline & $\mathrm{C} 3$ & 0.01 & 0.01 & 0.05 & -0.01 & -0.07 & 0.24 & -0.01 & 0.00 & 0.10 & $0.31 * *$ \\
\hline & $\mathrm{C} 4$ & 0.00 & 0.00 & 0.01 & 0.02 & 0.12 & 0.33 & 0.00 & 0.02 & -0.01 & $0.49 * *$ \\
\hline \multirow{4}{*}{$\begin{array}{l}\text { Number of } \\
\text { pods per } \\
\text { plant }\end{array}$} & $\mathrm{C} 1$ & 0.00 & 0.01 & 0.01 & 0.04 & 0.00 & 0.76 & 0.00 & 0.01 & 0.10 & $0.94 * *$ \\
\hline & $\mathrm{C} 2$ & 0.00 & 0.00 & 0.01 & -0.02 & 0.00 & 0.93 & 0.01 & 0.00 & 0.01 & $0.94 * *$ \\
\hline & $\mathrm{C} 3$ & 0.01 & 0.01 & 0.12 & -0.02 & -0.03 & 0.46 & 0.00 & 0.00 & 0.18 & $0.70 * *$ \\
\hline & C4 & 0.00 & 0.00 & 0.01 & 0.06 & 0.05 & 0.78 & -0.01 & 0.03 & -0.01 & $0.92 * *$ \\
\hline \multirow{4}{*}{$\begin{array}{l}\text { Pod length } \\
(\mathrm{cm})\end{array}$} & $\mathrm{C} 1$ & 0.00 & 0.00 & 0.00 & 0.00 & 0.00 & 0.03 & -0.07 & 0.08 & 0.01 & 0.06 \\
\hline & $\mathrm{C} 2$ & 0.01 & 0.00 & 0.00 & 0.00 & 0.00 & 0.17 & 0.03 & -0.01 & 0.00 & $0.19 *$ \\
\hline & $\mathrm{C} 3$ & 0.01 & 0.00 & -0.01 & 0.00 & -0.01 & 0.02 & -0.05 & -0.01 & 0.05 & -0.01 \\
\hline & C4 & 0.00 & 0.00 & 0.01 & 0.02 & 0.02 & 0.26 & -0.02 & 0.05 & 0.01 & $0.35 * *$ \\
\hline \multirow{4}{*}{$\begin{array}{l}\text { Number of } \\
\text { seeds per pod }\end{array}$} & $\mathrm{C} 1$ & 0.00 & 0.00 & 0.00 & 0.00 & 0.00 & 0.07 & -0.05 & 0.10 & 0.01 & 0.13 \\
\hline & $\mathrm{C} 2$ & 0.00 & 0.00 & 0.00 & 0.00 & 0.00 & 0.19 & 0.02 & -0.01 & 0.00 & $0.21 *$ \\
\hline & $\mathrm{C} 3$ & 0.00 & 0.00 & 0.02 & 0.00 & -0.01 & 0.05 & -0.02 & -0.03 & 0.05 & 0.05 \\
\hline & $\mathrm{C} 4$ & 0.00 & 0.00 & 0.01 & 0.03 & 0.03 & 0.32 & -0.02 & 0.08 & 0.01 & $0.45 * *$ \\
\hline \multirow{4}{*}{$\begin{array}{l}\text { 100-seed } \\
\text { weight (g) }\end{array}$} & $\mathrm{C} 1$ & 0.00 & 0.01 & 0.01 & 0.02 & 0.00 & 0.44 & 0.00 & 0.01 & 0.18 & $0.66 * *$ \\
\hline & $\mathrm{C} 2$ & 0.00 & 0.00 & 0.00 & -0.01 & 0.00 & 0.28 & 0.00 & 0.00 & 0.02 & $0.29 * *$ \\
\hline & $\mathrm{C} 3$ & 0.00 & 0.00 & 0.10 & -0.01 & -0.02 & 0.20 & -0.01 & 0.00 & 0.41 & $0.67 * *$ \\
\hline & C4 & 0.00 & 0.00 & 0.00 & -0.01 & -0.01 & -0.09 & 0.00 & 0.00 & 0.11 & 0.00 \\
\hline
\end{tabular}

Residual effects: 0.30 (C1); 0.33 (C2); 0.54 (C3); 0.37 (C4)

C1-VBN(Bg) 4 x CO 5; C2-VBN(Bg) 4 x APK 1; C3-VBN(Bg) 4 x Mash 1008; C4-CO 5 x TU 68

${ }^{*}$ Bold figures denote direct effects.

*, ${ }^{* *}$ Significant at $5 \%$ and $1 \%$ level of probability, respectively. 
Association studies used to select the desirable yield attributing traits to improve the seed yield. In this study, the traits viz., plant height, number of branches per plant, number of clusters per plant, number of pods per plant recorded significant and positive correlation with seed yield per plant in all four crosses (Table 2). These results are in close agreement with Sathya et al. (2018) for plant height, Dheeraj et al. (2020) for number of branches per plant, Sridhar et al. (2019) for the number of clusters per plant, and Teja and Lal (2021) for the number of pods per plant. The number of pods per cluster recorded a positive and significant correlation with seed yield in all the cross except VBN(Bg) 4 x APK 1. Reddy et al. (2020) observed a similar finding. Pod length recorded a significant and positive correlation with yield in VBN(Bg) $4 \times$ APK 1 and CO $5 x$ TU 68. Similar results were reported by Sathees et al. (2019). Number of seeds per pod recorded a significant and positive correlation with seed yield in only one cross CO 5 x TU 68. Gomathi et al. (2020) observed similar findings. The trait 100-seed weight recorded a significant and positive correlation with seed yield per plant in all the crosses except CO 5 $x$ TU 68. These results are in close agreement with Radhikaben and Bala (2020).

Path coefficient analysis helps partition the correlation coefficient into its direct and indirect effects (Table 3 ). In the present study, number of pods per plant had a high and positive direct effect on seed yield in all four populations. The trait 100-seed weight recorded a high and positive direct effect on seed yield in the cross $\operatorname{VBN}(\mathrm{Bg}) 4 \mathrm{x}$ Mash 1008 alone. Number of branches per plant recorded moderate and positive direct effect on seed yield in the cross VBN(Bg) 4 x Mash 1008 . Number of pods per cluster and number of seeds per pod recorded low and positive direct effect on seed yield in CO $5 \times$ TU 68 and VBN(Bg) 4 x CO 5, respectively. , The residual effect of all four crosses, was ranged between 0.30-0.54. It clearly explains the observedcharacters were more appropriate for the path analysis on seed yield per plant. These results are in close agreement with Sathya et al. (2018) for high direct effect on number of pods per plant, Gomathi et al. (2020) for high direct effect on 100 - seed weight. Among various traits, number of pods per plant alone showed high to moderate and positive indirect effects for most of the characteristics. Saran et al.(2020) reported a positive and high indirect effect on seed yield per plant via the number of pods per cluster and pod length.

\section{CONCLUSION}

Based on the previous discussion, it can be concluded that there was sufficient genetic variability in the segregating populations studied for all the characters. The traits viz., plant height, number of cluster per plant, number of pods per cluster, number of pods per plant, and seed yield per plant indicated high heritability along with high genetic advance as per cent of mean. Hence, the environment influenced these traits and possessed high genetic variability. Hence, selection can be practiced for these traits in these populations. Association studies revealed the plant height, number of branches per plant, number of clusters per plant, number of pods per cluster, number of pods per plant and 100-seed weight were positive and significant association with seed yield per plant. The path analysis indicated that number of pods per plant had positive and high direct effects. Most of the traits also had high to moderate positive indirect effects via number of pods per plant. However other characteristics like 100-seed weight and number of branches per plant had high or moderate and positive direct effect in the cross $\operatorname{VBN}(\mathrm{Bg}) 4 \times \mathrm{CO}$ 5 alone. Hence, based on correlation and path analyses, it can be concluded that the number of pods per plant can be considered as selection index for the seed yield improvement programme in blackgram. However, population-specific selection indices are preferred as the association of traits varies with the populations.

\section{ACKNOWLEDGEMENTS \& FUNDING}

Authors acknowledge the help rendered by Mr. Arul Doss, Agricultural Supervisor, NPRC, Vamban in the trial.No funds were received for this research.

\section{Ethics approval}

The author declares that the study performed is true with novelty in the interpretations.

\section{Conflicts of interest/Competing interests:}

The authors declare that the research was conducted in the absence of any commercial or financial relationships that could be construed as a potential conflict of interest.

\section{REFERENCE}

Anuradha, N., Patro, T. S. S. K., Triveni, U. and Rajkumar, P. J. R. S. 2020. Character association and variability studies in black gram advanced breeding lines. J. Pharmacogn. Phytochem., 9(1): 1880-1882.

Bandi, H. R. K., Rao, K. N., Krishna, K. V. and Srinivasulu, K. 2018. Variability, heritability and genetic advance for quantitative characters in rice fallow black gram [Vigna mungo (L.) Hepper]. Int. J. Curr. Microbiol. App. Sci., 7(2): 171-176.

Bishnoi, A., Gupta, P., Meghawal, D. R. and Lal, G. M. 2017. Evaluation of genetic variability and heritability in blackgram (Vigna mungo (L.) Hepper) genotypes. J. pharmacogn. phytochem.,6(4): 493496. 
Burton, G. W. (1952). Quantitative inheritance in grasses. Pro VI International Grass Congress, 1952, 277-283.

Dewey, D. R. and Lu, K. (1959). A Correlation and PathCoefficient Analysis of Components of Crested Wheatgrass Seed Production 1. J. Agron., 51(9): 515-518.

Dheeraj, A. G., Lavanya, G. R., Kumar, P. P. and Sanadya, S. K. 2020. Mean Performance and Correlation Coefficient Analysis for Seed Yield and Related Traits in Blackgram Parents and Crosses. Int.J.Curr. Microbiol.App.Sci., Special Issue-11: 1972-1977

Falconer, D. S. (1960). Introduction to quantitative genetics: Oliver And Boyd; Edinburgh; London.

Gomathi, D., Shoba, D., Ramamoorthy, V. and Pillai, M. A. 2020. Studies on Variability, Heritability, Correlation and Path Analysis in Segregating Population of Black Gram [Vigna mungo (L.) Hepper]. Legum. Res., 1: 5.

Johnson, H. W., Robinson, H., and Comstock, R. 1955. Estimates of genetic and environmental variability in soybeans 1. J. Agron., 47(7): 314-318.

Kumar, B. S., Padmavathi, S., Prakash, M. and Ganesan, J. 2003. Correlation and path analysis in black gram [Vigna mungo (L.) Hepper]. Legum. Res.,26(1): 75-76.

Lush, J. L. (1949). Heritability of quantitative characters in farm animals. Hereditas., 35(S1): 356-375.

Manivannan, N. 2014. TNAUSTAT-Statistical package. Retrieved from https://sites. google. c o m/ site/tnaustat.

Nadarajan, N., Manivannan, N. and Gunasekaran, M. 2018. Quantitative genetics and biometrical techniques in plant breeding. Kalyan publishers, New Delhi.

Radhikaben, N. P. and Bala, M. 2020. Correlation Studies for Yield and its Components in Black Gram [Vigna mungo (L.) Hepper]. Int. J. Curr. Microbiol. App. Sci., 9(9): 1441-1447.
Reddy, A. K., Priya, M. S., Reddy, D. M. and Ravindra, B. 2020. Correlation and path coefficient analysis for yield, yield components and water use efficiency traits in blackgram under organic fertilizer management. J. Pharmacogn. Phytochem., 9(6): 2050-2052.

Saran, R., Sharma, P. P. and Tank, H. K. 2020. Character Association for Seed Yield and its Contributing Traits in Blackgram [ Vigna mungo (L.) Hepper]. Int. J. Curr. Microbiol. App. Sci., 9(4): 2029-2033.

Sathees, N., Shoba, D., Saravanan, S., Merina prem Kumari, S. and Arumugam Pillai, M. 2019. Studies on Genetic Variability, Association and Path Coefficient Analysis in Black Gram (Vigna mungo L. Hepper). Int. J. Curr. Microbiol. App. Sci., 8(6): 1892-1899.

Sathya, P., Manivannan, N., Mahalingam, A., Satya, V. K. and Parameswari, C. 2018. Association analysis for seed yield and component traits in segregating populations of blackgram (Vigna mungo (L.) Hepper). Electron. J. Plant Breed., 9(2): 741-746.

Sridhar, V., Prasad, B. V., Shivani, D. and Rao, S. S. 2020. Studies on Character Association and Path Coefficient Analysis for Yield Components in Blackgram (Vigna mungo (L). Hepper Genotypes. Int. J. Curr. Microbiol. App. Sci., 9(1): 1824-1830.

Sushmitharaj, D. V., Shoba, D. and Pillai, M. A. 2018. Genetic variability and correlation studies in black gram (Vigna mungo [L.] hepper) with reference to YMV resistance. Int. J. Curr. Microbiol. App. Sci., SP(6):2849-2856.

Teja, M. K. V. and Lal, G. M. 2021. Study of genetic variability and character association for yield and yield related traits in $\mathrm{f3}$ generation of blackgram (Vigna mungo (L.) Hepper).Int. J. Agric. environ. Biotechnol., 6: 3.

Thirumalai, R. and Murugan, S. 2020. Multivariate analysis in blackgram (Vigna mungo (L.) hepper) genotypes for mungbean yellow mosaic virus (mymv) resistance. Plant Arch., 20(1): 2473-2480. 